characteristics of performing art on the example of Russian piano music. Conclusions and prospects for further scientific research. In the context of global integration processes, in the conditions of which musical art and musical pedagogy are developing today, this phenomenon takes on special significance, since it is associated with the specificity of the artistic realization of national quality inherent in a particular cultural tradition. For Chinese musical pedagogy, this is especially relevant, since at the present stage of its development it is fundamentally oriented towards development of European musical culture and penetration of its national-mental features, including those in the field of piano performing art. Significant differences in the established traditions of musical performance in China and Europe, Russia and Ukraine, among others, cause the need to understand the significance of the national factor in the formation of an individual performing style. National factors of the performing style are associated with the individual psychological characteristics of the composer and performer. Their musical realization consists in the dominance of certain psychological states in the musical opus and its interpretation. Accordingly, it can be argued that the national indicator of the performing style is a "sounding mind", an expression of mentality at the level of individual reading of the musical text. The national factor in the performing arts can be viewed at the level of tradition, which incorporates the totality of cultural representations of both the author of a musical work and its interpreter. These performances perform the main function in shaping the individual style of music performance. The study of the national cultural component of the performing style greatly expands the theoretical knowledge and ideas of students, which forms their performing competence and their professional competence. This position actualizes pedagogical development of the national aspects of the piano performing art of China and Ukraine.

Key words: style, performing style, interpretation, national culture, national style, professional competence, tradition.

UDC [811.124:61]:378-057.876

Svitlana Polyuha

Higher Educational Establishment

Ukrainian Catholic University

ORCID ID 0000-0003-3939-9285

DOI 10.24139/2312-5993/2019.05/160-170

\title{
PEDAGOGICAL TECHNIQUES IN THE FORMATION OF PROFESSIONAL MEDICAL SKILLS IN THE PROCESS OF LEARNING LATIN
}

The aim of the study was to evaluate the quality of professional training of students in higher medical education institutions and faculties, which prepare narrow profile medical specialists. The object of the study was the students of the university "Ukrainian Catholic University». The article convincingly proves that active forms of carrying out classes in the Latin language train brain activity, develop an interest in knowledge of professional terminology and form multicultural competences of an educated specialist-physician. Simulation of situations provides intensification of intellectual activity, and practical application contributes to the expansion of the lexical stock. To determine the level of students' vocabulary mastery it is expedient to use elements of the suggestive method, showing drawings or certain actions, to teach students to use dictionaries of synonyms, antonyms, definitions and other thematic glossaries.

Key words: Greek-Latin scientific terminology system, terminological element, Latin language, interactive methods, motivation, scientific and methodological support. 
Introduction. Modern conditions of the open intellectual space create new challenges in the process of pedagogical practice in education. The issue of organizing vocational training of qualified specialists from different fields requires active participation of all subjects of the educational process. In the light of world standards and needs, introduction of new educational technologies with regard to professional needs becomes topical. In order to optimize the process of teaching and objective evaluation of knowledge acquisition of humanitarian subjects, in particular, the study of the Latin language, innovative methods are applied. The main goal of the introduction of such training is formation of the student's personality, his/her intellectual and creative abilities that influence the quality of knowledge.

Actuality of the topic of this study is dedicated to studying of the Latin language in medical schools as in medical area it has its own peculiarities which differ from its teaching in other branches of education. Taking into account the objective significance of high-quality professional medical training and the actuality of the skills of forming special terminology in professional activity, it is necessary to determine the role of the methodology of teaching medical terminology in the professional training of a physician. The concept is focused on a specialist capable, within the limits of his/her specialty, to realize a complex of medical and rehabilitation measures, to assess the state of physical health of a patient and to predict ways of effective activity in the process of recovery. The priority task in the study of the Latin language in the field of medical education is implementation of the educational process through integration of educational and medical activities (Tsekhmister, 2002). The structure of such study of medical terminology is based on the system-terminology principle and provides for deep knowledge and practical skills for working with international nomenclatures, the study of special literature, where teaching of Latin grammar is based on the Greek-Latin linguistic core and is specified by examples of anatomic-histological, clinical and pharmaceutical terminology.

Analysis of relevant research. A significant contribution to the development of the teaching method of medical Latin in Ukrainian studies was made by V.Shovkovyi, T. Storchova, O. Panteleieva (Storchova, 2014; Shovkovyi, 2002). Among the textbooks in Latin with the basics of medical terminology, some of the most popular ones are the works of M. Zakaliuzhnyi, O. Kiseliova, E. Svetlichna, O. Mikhailova, H. Kononko, L. Smolska, and other modern scholars. It is worth noting the textbooks of such foreign authors as William Thomas St. Clair, D. R. Langslow, Erzsebet Belak, A. J. Cooley, 
D. K. Kondratiev, A. Z. Tsisyk and others, which clearly illustrate means of the auditorium and independent work of students and develop their research skills.

The aim of the study is to comprehensively define and systematize the necessary components to ensure teaching of the Latin language in the context of the requirements for training of a highly qualified medical specialist, application of different types and forms of work of students who can competently use medical terminology in practice.

Materials and methods. The object of the study was the students of the university "Ukrainian Catholic University». To achieve this goal, the method of theoretical analysis and generalization of scientific and methodological literature of Ukrainian and foreign authors, the method of comparative-historical analysis and a comparative method for determining the relationship between the names in Latin and Greek in the formation of medical terminology was used.

In the academic group, when studying similar grammar teaching material, a comparative method is used. At the training stage, a number of exercises are proposed that include comparison of Latin and Greek languages. In practice, this method is used to correct the students' knowledge, which leads to a number of logical and grammatical theoretical tasks and formation of grammatical and lexical competences of students. As the experience shows, an interdependent method is most appropriate for the formation of linguistic competence or abstract linguistic thinking. During such classes it is necessary to take into account the individual possibilities of each student to argue presentation of thoughts.

Results and Discussion. The Latin language, though it belongs to the linguistic block of disciplines, in the field of medical profile is almost the first subject that introduces future physicians to anatomic-histological, clinical and pharmaceutical terminology. This distribution corresponds to the main branches of medicine: research on the structure of the human body, inner organs and tissue structure; study of the causes and methods of disease treatment; study of the variety of medicinal products, their origin, manufacture and influence on the body. In today's educational process, where the technology of interactive learning is rapidly developing, it is difficult to convey to students dry material of the basics of Latin grammar and to control significant lexical material. For this reason, it is necessary to fill the classes with methods that promote involvement of different types of thinking.

The first task for a Latin language teacher is to show students the difference between terminology and nomenclature. With the help of terminology, human experience in exploring and development of the environment is accumulated and transmitted (Polyuha, 2018). The very notion 
«term» does not have an explicit concrete interpretation, and therefore this linguistic reality gets different definitions. When we consider terminology as a certain stratum of general literary vocabulary, as a professional terminology system, we experience some difficulties in understanding what is terminology (a term), since the content structure of a large part of commonly used words includes, at the same time, comprehensible meanings as well as terminology. Linguists who study the term as part of its terminology system take a corresponding word with the terminology for its independent unit (Lotte, 1982). Unlike the terminology, the nomenclature defines a set of standardized names that arose as a consequence of the systematization or classification of scientific concepts. Physicians use the international code of officially registered lists of terms written in Latin for the principle of universality in order to comply with the international rules of application of the scientific nomenclature.

Terminological approach visualized by artistic means continues to be the most effective in the study of the medical Latin. To master the Latin-Greek wordbuilding elements, students need to learn to see the grammatical structure of a word, to be able to analyze the affixes, root, basis, and endings in the word. The most important means of word formation in medical terminology are suffixes; they give the words new shades, change the lexical and grammatical meaning of derivative words, and often have a stable semantic meaning.

Prefixes and suffixes in the medical nomenclature are the most important terminological elements that express the information on the classification of terms. For example, the addition of a noun or an adjective of diminutive suffixes to the base of the noun or adjective produces deminuts that are widely used in the anatomical and histological terminology (alveus alveŏlus; cella - cellŭla). For the successful study of such prefix-suffix terminology series it is expedient to use in practice classes such methods of work in pairs and groups as "brainstorming" or an educational game. Students get the task of creating as many examples as possible from a certain foundation or with certain affixes. Such technology encourages students to remember as much vocabulary as possible, provides interdisciplinary integration and collaboration with disciplines: anatomy, physiology, pharmacology, and botany.

When analyzing the structure of medical terms it is important to teach students to notice the related lexical family. For successful training in this area, our own experience allows us to advise on the feasibility of using educational projects that need to be implemented in a short time, aimed at studying linguistic peculiarities, and the formation of students' research competence. Here we can offer projects of multimedia work or on compilation of thematic 
dictionaries and various tables: from grammatical structures of terminology to the study of the etymology of nomenclature names. Topics on the study of the use of mythologies (motivated or indifferent) in anatomy, clinic, pharmacology and biological nomenclature are also interesting for medical students.

In medicine, there are terms that originally can be attributed to various time, cultural and historical segments: mythological (from antiquity), Biblical (from the Middle Ages), terms on astrology and chiromancy (from the Renaissance). There are words that reflect the history and other spheres of human culture. The culturological excursion into the etymology of medical terms reveals a huge list of Greek-Roman gods, demons, heroes and other fantastic creatures:

- membrana arachnoidea-spider-like membrane, shell;

- pomum Adami - laryngeal prominence;

- cornu Ammonis - Amonium horn;

- Morphinum - morphine;

- Mercusalum - mercusale;

- Arthemisia - wormwood, plant of Artemis, the goddess of hunting.

As experience shows, such tasks increase students' cognitive interest and promote strengthening of learning motivation in the group. The creative approach to making a presentation orientates the person to the development and opening of communicative skills, forms the ability to rationalize his/her own opinion and convincingly present his/her own opinion, socializing in front of the audience.

For the study and consolidation of vocabulary, the semantics of which are the same for different languages, we can suggest the group to work with foreign dictionaries and in the conversation mode to organize the characteristics of medical concepts. It should be remembered that the Greek language, until the crisis of the ancient world, actually served as the function of the international language of medicine, its legacy contains the names of many diseases and symptoms:

- dyspnoë-bad breath;

- melancholia - refers to black bile;

- amaurosis - amarrose, blindness (from Gr. - dark);

- symphysis - symphysis, fusion;

- catarrhos - inflammation of the mucous membrane;

- dyspepsia-dyspepsia, digestive disorder.

Presenting material on the internal form and semantics of medical names allows us to complement the processes of knowledge of the collective activity of participants, allows the teacher to understand the directions of mastering 
the thinking of medical students in the field of medical experience; and shows which of the signs of illness their consciousness chooses for naming. Teachers may give groups of students a task to classify the medical names for: external signs of the disease, their similarity to the surrounding realities, subjective sensations of the patient, the causes of the disease (Shumylo, 2014):

- diabetes - go through;

- diarrhea - flow;

- diaphragm - fence;

- diagnosis - examine, recognize;

- eczema - boil;

- a placenta - flat plate.

Thus, it is evident from the examples given that a number of terms from the Greek-Latin records are used today, some with minor modification or without change (arthritis, nephritis, pleuritis).

Problem-situational learning as a modern method in a regular classroom Latin language lesson can be applied when students learn to write a prescription. This type of learning involves immersing group members into a specific problem and finding a practical solution to a situational task through reflections and knowledge gained in the educational process in general.

A scientific presentation is an extremely powerful method that promotes formation of important professional qualities and independent thinking. It is important for a teacher to timely notice among students the persons with deep creative thinking and to start working in the scientific space with such initiative and ambitious personalities, involving them in thematic student conferences. The topics of the speeches are multifaceted: from mythology, the history of medicine to specific studies of vocabulary in anatomy or clinical terminology on the basis of the Latin language.

With confidence one can rely on various psychological opportunities, implementation of which successfully forms the skills of speech, such as organization of a discussion club, where students receive a variety of booklets with vivid advertising of medications, their composition and recommendations for treatment. Students receive the task of classifying and explaining their choice based on the Latin words in the ad text.

The texts of moral, ethical and educational orientation also play an important role in learning and are used as illustrations of Latin proverbs and aphorisms.

In round-table discussions, it is very effective to read and analyze professional texts of a thematic nature («De corpore humano», "De cranio», "De 
musculis», «De tunicis», «De cordis et morbis cardiacis», «Musculi membri superires et membri inferiores» etc.). It is important to use mnemonic - a method of storing information as a technique of visual memorization and apply encyclopaedic, explanatory and illustrated medical dictionaries (Illustrated Dorland Dictionary, 2002). This gives a deep understanding of the material, since the methods of memorization create figurative illustrations for the definitions in the imagination and contribute to a qualitative study of the thematic vocabulary.

Qualitative indicators of grammatical knowledge, skills and abilities are determined by criteria of logic and ability to argue the presentation of opinions. Quantitative indicators are the criteria of exhaustion, correctness of the information presentation, orthographic literacy (Shovkovyi, 2002). Based on theoretical sources on the methodology of teaching foreign languages, we have identified control objects, criteria and norms for assessing the grammatical competence of medical students.

Table 1

\section{Criteria and norms for assessing the grammatical competence of medical students}

\begin{tabular}{|l|l|}
\hline \multicolumn{1}{|c|}{ Object of control } & \multicolumn{1}{|c|}{ Evaluation criteria } \\
\hline $\begin{array}{l}\text { Ability to form a complete paradigm of } \\
\text { the word }\end{array}$ & comprehensiveness and accuracy \\
\hline Ability to form selective forms & correctness \\
\hline Ability to define grammatical forms & comprehensiveness, correctness \\
\hline $\begin{array}{l}\text { Knowledge of phonetic phenomena and } \\
\text { lexical units necessary to study grammar }\end{array}$ & $\begin{array}{l}\text { comprehensiveness, } \\
\text { orthographic literacy }\end{array}$ \\
\hline $\begin{array}{l}\text { Knowledge of words with the wrong } \\
\text { paradigm and ability to explain the } \\
\text { causes of anomalies or derivatives }\end{array}$ & $\begin{array}{l}\text { comprehensiveness, } \\
\text { orthographic literacy }\end{array}$ \\
\hline $\begin{array}{l}\text { Knowledge of the basic ways of } \\
\text { organizing the sentence }\end{array}$ & comprehensiveness, correctness \\
\hline
\end{tabular}

The peculiarity of teaching Latin in a medical institution is that Latin is a semantic base for mastering lexical material of a foreign language and is the basis for the study of medical terms in the English language (Glendinning, 2007). Also, with proper organization of training and proper scientific and methodological support, it is possible to provide high-quality study of foreign and Latin languages. 
Conclusions. During this methodological study, we have received a number of conclusions and practical recommendations that are of great importance in the study of the Latin language with medical terminology for the professional training of physicians. First of all, it has been discovered that it is necessary to systematically guide students to compare Latin and Greek languages.

For medical students the study of the Latin language is of particular importance. The profession of a medical doctor involves direct communication with a team and patients in the professional, administrative and scientific spheres. Its success will depend on both the general qualification of the doctor, and on the style of work, his/her business and moral qualities and values. And it is the teacher who has to create educational and methodological material for the preparation of students, taking into account the value-education moments and the cultural component of an educated specialist capable competently, and sometimes with a certain irony, of using pharmaceutical and clinical Latin terminology in practice (Hutsol, 2017).

An interactive approach to the organization of the educational process promotes development of student's thinking, formation of personal development skills, communication, mutual respect and teamwork.

The conducted research in the group of students of the specialty "physical therapist" made it possible to formulate a series of methodological recommendations on the effective use of methods for their vocational training and mobility in the educational process:

- Knowledge of the formal side of grammar;

- Knowledge of grammatical anomalies and the ability to determine the causes of their occurrence;

- Understanding the content of the grammatical phenomenon, ability to separate it from the form;

- Interlingual mobility in the students' minds;

- Ability to establish formal and functional-semantic relations between grammatical phenomena;

- Knowledge of phonetic phenomena and lexical units necessary for the study of grammar;

- General philological knowledge;

- Ability to adequately translate text.

At the present stage, for the training of a medical specialist, scientific reasoning for the didactic and methodological foundations for constructing professionally oriented Latin courses is important, which will contribute to the promising development of research in this field. Advanced pedagogical experience 
convinces that the correct methodology for teaching medical terminology and introduction of reading medical and scientific works into the program forms both a qualified specialist that meets the standards of higher medical education, and a new generation of teachers who are capable of teaching and educating a generation of culturally educated medical students (Kiselova, 2013).

Prospects for the use of results. The outcomes obtained as a result of methodological observations may become the basis or guidelines for the creation of a teaching manual on how to teach the Latin language and the basics of medical terminology.

\section{REFERENCES}

Гуцол М.І., (2017). Методика викладання латинської та іноземної мов в умовах кредитно-модульної системи у вищих навчальних закладах України. Свim медицини та біологіï, 3 (61), 190-194 (Hutsol, M. І., (2017). Methods of teaching Latin and foreign languages in terms of credit-module system in higher medical education institutions of Ukraine. World of Medicine and Biology, 3 (61), 190-194). DOI: 10.26724 / 2079-8334-2017-3-61-190-194

Ілюстрований медичний словник Дорланда: в 2 m. (2002). (Illustrated Dorland Dictionary in Two Volumes). W.B. Saunders company division of Elsevier science st. 1042 Philadelphia, Pennsylvania, USA. Nautilus publishing house Lviv, Ukraine, V. I. - 1354 p.; V. 2. - 2687 p.

Кисельова, О. Г. (2013). Методика навчання медичної термінології майбутніх лікарів. Педагогічний процес: теорія і практика, 4, 62-68 (Kiseliova, О. Н. (2013). Methodology for medical terminology training for future physicians. Pedagogical Process: Theory and Practice, 4, 62-68). Retrieved from: http://nbuv.gov.ua/UJRN/pptp 201349.

Лотте, Д. С., (1982). Вопросы заимствования и упорядочения иноязычных терминов и терминоэлементов (Lotte, L. S. (1982). Questions of borrowing and ordering of foreign terms and term elements). Retrieved from: https://dlib.rsl. ru/01001111712.

Полюга, С. М. (2018). Автентична позиція Граматики «Адельфотес»: виклики та перспективи. Актуальні питання суспільних наук та історії медицини. Спільний українсько-румунський науковий журнал, 3 (19), 14-18 (Polyuha, S. M. (2018). Authentic position Grammar "Adelfotes»: challenges and prospects. Current issues of Social sciences and History of Medicine. Joint Ukrainian-Romanian scientific journal, 3 (19), 14-18). DOI: 10.24061/2411-6181.3.2018.49

Сторчова, Т.В. (2014). Етапи становлення навчальної дисципліни «Латинська мова»: європейський та вітчизняний досвід. Педагогічна освіта: теорія і практика, 16, 187-191 (Storchova, T. V. (2014). Stages of the formation of the discipline "Latin": European and national experience. Pedagogical Education: Theory and Practice, 16, 187-191). Retrieved from: http://nbuv.gov.ua /UJRN/ znppo 20141637.

Шовковий, В. М. (2002). Історія зіставного методу у теорії та практиці викладання класичних мов. Теоретичні питання культури, освіти та виховання, 23, 101106 (Shovkovyi, V. M. (2002). The history of a comparative method in the theory and practice of teaching classical languages. Theoretical issues of Culture, Education and Upbringing,_23, 101-106.

Шумило, М. Ю. (2014). Відображення міфологічних греко-латинських термінів у мові медицини. Наукові записки Національного університету «Острозька академія», 45, 70-73 (Shumylo, M. Yu. (2014). The reflection of mythological Greek- 
Latin terms in the language of medicine. The Scientific notes of the National University "Ostroh Academy», 45, 70-73). Retrieved from: https://lingvj.oa.edu.ua/assets/files/full/2017/NZ Ukr filol Vyp 68.pdf

Цехмістер, Я. В. (2002). Теорія і практика допрофесійної підготовки учнів у ліцеях медичного профрілю при вищих навчальних закладах (дис. ... д-ра пед. наук: 13.00.04). Київ (Tsekhmister, Ya. V. (2002). Theory and practice of pre-professional training of students in the lyceums of medical profile at higher education institutions (PhD thesis)).

Glendinning, E. H. (2007). Professional English in Use (Medicine). Eric H. Glendinning, Ron Howard. Cambridge University Press. Retrieved from: https://trove. nla.gov.au/version/44903135

\section{PEЗЮME}

Полюга Светлана. Педагогические техники в формировании профессиональных навыков медика в процессе изучения латинского языка.

Статья посвящена проблеме повышения качества профессиональной подготовки студентов в высших медицинских учебных заведениях и факультетах, готовящих узкого профиля медицинских специалистов. В статье проанализирована необходимость внедрения в учебный процесс учебных заведений методики изучения медицинской терминологии, которая способна обеспечить направление прочесса получения образования на будущую профессиональную деятельность через доскональное изучение латинского языка. В статье убедительно доказано, что активные формы проведения занятий по латинскому языку тренируют мозговую деятельность, развивают интерес к обладанию профессиональной терминологией и фрормируют многокультурные компетенции образованного специалиста-медика.

Ключевые слова: греко-латинская научная терминосистема, терминоэлемент, латинский язык, интерактивные методы, мотивация, научнометодическое обеспечение.

\section{АНОТАЦІЯ}

Полюга Світлана. Педагогічні техніки у формуванні професійних навичок медика у процесі вивчення латинської мови.

Стаття присвячена проблемі підвищення якості професійної підготовки студентів у медичних закладах вищої освіти та факультетах, що готують медичних фрахівців вузького профрілю. у статті проаналізовано необхідність упровадження в освітній прочес означених закладів методики вивчення медичної термінології, яка здатна забезпечити спрямування процесу здобуття освіти на майбутню професійну діяльність через досконале вивчення латинської мови. У статті переконливо доведено, що активні форми проведення занять з латинської мови тренують мозкову діяльність, розвивають інтерес до володіння фаховою термінологією та формують багатокультурні компетенції освіченого фахівцямедика. Структура такого вивчення медичної термінології базується на системнотермінологічному принципі й передбачає глибоке знання та володіння практичними навичками для роботи з міжнародними номенклатурами, дослідженням спеціальної літератури, коли викладання латинської граматики ґрунтується на греколатинському лінгвістичному ядрі та конкретизується прикладами з анатомогістологічної, клінічної, фрармацевтичної терміносистем. Для досягнення поставленої мети використано метод теоретичного аналізу та узагальнення науково-методичної літератури українських та іноземних авторів, метод компаративно-історичного аналізу та зіставний метод для визначення 
взаємозв'язків між найменуваннями в латинській та грецькій мові при фрормуванні медичної термінології. При моделюванні ситуацій відбувається активізація інтелектуальної діяльності, а практичне застосування сприяє розширенню лексичного запасу. Для визначення рівня опанування студентами лексики дочільно використовувати елементи сугестивного методу, демонструючи малюнки чи певні дії, вчити студентів послуговуватися словниками синонімів, антонімів, дефініцій та іншими тематичними глосаріями.

Ключові слова: греко-латинська наукова терміносистема, терміноелемент, латинська мова, інтерактивні методи, мотивація, науково-методичне забезпечення.

УДК 796.011.3

Анна Сахненко

Сумський державний педагогічний

університет імені А. С. Макаренка

ORCID ID 0000-0002-8084-3897

DOI 10.24139/2312-5993/2019.05/170-183

\section{АНАЛІЗ РІВНЯ ПРОФЕСІЙНО-ПРИКЛАДНОЇ ОБІЗНАНОСТІ СТУДЕНТІВ АГРАРНИХ СПЕЦІАЛЬНОСТЕЙ}

У представленій статmі розглянуто структуру профресійно-прикладної фізичної підготовки студентів закладів вищої освіти. Досліджено рівень професійноприкладної обізнаності студентської молоді аграрних спечіальностей. Установлено, що теоретична складова професійно-прикладної фізичної підготовки значно впливає на формування системи теоретичних і практичних знань студентів, необхідних майбутнім фрахівцям агропромислового комплексу у професійній діяльності й побуті. Аналіз анкетних даних дозволив констатувати недостатній рівень знань майбутніх фахівців агропромислового комплексу в галузі фрізичної культури, спорту, здорового способу життя і професійно-прикладної фрізичної підготовки.

Ключові слова: профресійно-прикладна обізнаність, фізичне виховання, рівень, компонент, обсяг знань, студенти аграрних спеціальностей.

Постановка проблеми. На сучасному етапі свого розвитку промисловість нашої країни відчуває потребу в освічених, висококваліфікованих фахівцях, які володіють фундаментальними знаннями, професійними вміннями та навичками, досвідом творчого вирішення нових актуальних проблем та здатністю до самореалізації навичок і вмінь у різних сферах професійної діяльності. Основною складовою економіки України є агропромисловий комплекс, що поєднує в собі виробництво сільськогосподарської продукції, ії сільськогосподарську переробку й матеріально-технічне обслуговування села (Сахненко та Коломієць, 2018).

Однак, аграрна промисловість нашої країни останнім часом гостро відчуває брак кваліфікованих спеціалістів. Однією з головних причин 